\title{
ZMIANY W RAPORTOWANIU CSR W POLSCE - STUDIUM PRZYPADKU
}

\author{
Anna Badura-Mojza \\ Katedra Finansów Przedsiębiorstw i Ubezpieczeń Gospodarczych \\ Uniwersytet Ekonomiczny w Katowicach
}

\begin{abstract}
Abstrakt. Celem artykułu jest przedstawienie zmian zachodzących w sprawozdawczości pozafinansowej oraz kanałów raportowania danych z zakresu CSR przez spółki notowane na głównym rynku Giełdy Papierów Wartościowych w Warszawie S.A. w ramach indeksu WIG 30. Z przeprowadzanych analiz wynika, iż spółki WIG 30 odchodzą od wykazywanie informacji z zakresu CSR w tradycyjnych sprawozdaniach finansowych, decydują się na ujawnianie danych z obszaru CSR w specjalnych raportach i na swoich witrynach internetowych. Ponadto polscy liderzy raportowania pozafinansowego zdecydowali się na sporządzania zintegrowanych raportów rocznych. Pomimo, że raportowanie społeczne w Polsce jest nadal nową dziedziną to praktyka wskazuje na dynamikę rozwoju w zakresie raportowania danych pozafinansowych.
\end{abstract}

Słowa kluczowe: społeczna odpowiedzialność przedsiębiorstw, raporty społeczne, sprawozdawczość pozafinansowa

\section{WPROWADZENIE}

Rozwój rynków kapitałowych, postępująca globalizacja i presja społeczeństwa oczekującego pogłębionych danych i transparentnych informacji przyczynia się do pozytywnych zmian w zakresie raportowania. W współczesnych gospodarkach dostępne dane finansowe są niewystarczającym źródłem nie tylko dla oceny kondycji przedsiębiorstw. Dostrzegła ten fakt również Komisja Unii Europejskiej, gdyż wprowadzając Dyrektywę UE 2014/95/UE zobligowała jednostki zaintere- 
sowania publicznego ${ }^{1}$ od 01 stycznia $2017 \mathrm{r}$. do publikowania informacji dotyczących kwestii różnorodności oraz ujawniania danych pozafinansowych ${ }^{2}$.

Celem opracowania jest przedstawienie zmian zachodzących w sprawozdawczości pozafinansowej oraz sposobów raportowania danych zakresu CSR (Corporate Social Responsibility) przez spółki notowane na głównym rynku Giełdy Papierów Wartościowych w Warszawie S.A. w ramach indeksu WIG 30.

\section{RAPORTOWANIE DANYCH Z ZAKRESU CSR}

Zgodnie z koncepcją $\mathrm{CSR}^{3}$ polegająca przede wszystkim na budowaniu trwałych i przejrzystych relacji z interesariuszami ${ }^{4}$ konieczne jest wykorzystywanie przez przedsiębiorstwa narzędzi umożliwiających przedstawianie danych pozafinansowych. Informacje dotyczące zaangażowania przedsiębiorstw w CSR znajdują swoje odzwierciedlenie nie tylko $\mathrm{w}$ obligatoryjnym sprawozdaniu rocznym, ale w specjalnych raportach dedykowanych opisywanej tematyce takich jak: raporty społeczne, raporty zrównoważonego rozwoju, raporty środowiskowe. Ponadto niektóre spółki prezentują podjęte inicjatywy z obszaru CSR w zintegrowanych

\footnotetext{
${ }^{1}$ Jednostki zainteresowania publicznego, których średnioroczne zatrudnienie wynosi powyżej 500 pracowników oraz w których suma bilansowa wynosi powyżej 20 mln EUR lub przychody netto powyżej $40 \mathrm{mln}$ EUR będą podlegały obligatoryjnemu raportowaniu informacji odnoszących się do takich kwestii jak opis polityk, ich wynik, ocena ryzyk, podstawy zarządcze, wskaźniki z zakresu przeciwdziałania korupcji, negatywnego wpływu na środowisko naturalne, aspektów pracowniczych, społecznych i poszanowania praw człowieka.

2 por. Dyrektywa UE 2014/95/UE w odniesieniu do ujawniania informacji niefinansowych i informacji dotyczących różnorodności przez niektóre duże spółki oraz grupy.

${ }^{3}$ Multidyscyplinarny wymiar pojęcia społeczna odpowiedzialność przedsiębiorstw - CSR (Corporate Social Responsibility) znajduje się w normie ISO 26000 Guidance on Social Responsibility, która definiuje CSR jako: „odpowiedzialność organizacji za wpływ jej decyzji i działań (produkty, serwis, procesy) na społeczeństwo i środowisko" [Zbiegień-Maciąg 1997, s. 48-49, Gasparski 2003, s. 51, Pindelski 2009, s. 106]. Warto podkreślić, iż w definicjach wywodzących się z zarządzania zwraca się uwagę na fakt, że CSR ma charakter strategiczny i dynamiczny, opiera się na ciągłym doskonaleniu i stałej współpracy ze wszystkimi interesariuszami. Rozwój koncepcji CSR por. Fijałkowska, 2012, s. 142-144.

${ }^{4}$ Pojęcie interesariusz (stakeholder) pojawiło się po raz pierwszy w memorandum Standford Resarch Institute w 1963 r., rozpowszechnione zostało jednak dopiero na początku lat 80. ubiegłego stulecia przez R.E. Freemana (twórca teorii interesariuszy) według którego „interesariuszem” jest każda osoba, która może wywierać wpływ na organizację lub na którą ta organizacja wywiera wpływ [Freeman 1984, s. 25]. Interesariuszami zatem są wszelkie osoby, społeczności, instytucje, organizacje, które mogą wpływać na przedsiębiorstwo oraz pozostają pod wpływem jego działalności, [szerzej Adamus-Matuszyńska 2017].
} 
raportach rocznych ${ }^{5}$ bądź tylko za pośrednictwem swoich witryn internetowych. Warto podkreślić, iż w anglojęzycznej literaturze przedmiotu z zakresu raportowania zrównoważonego rozwoju, społecznej odpowiedzialności najczęściej używane są następujące określenia: sustainble reporting, social reports, corporate responsibility reporting, ESG reporting (Environmental Social Governanse reporting), natomiast w Polsce raportowanie działań w obrębie CSR jest identyfikowane jako raportowanie społeczne, raport odpowiedzialnego biznesu, raportowanie CSR, raportowanie zrównoważonego rozwoju [Eccles, Kurzus 2010, Gazdar 2007, Sroka, Grzymisławski, Kustra 2012, CRSinfo 2013]. Raportowanie społeczne to przedstawianie opinii publicznej w formie dokumentu danych dotyczących podejmowanych przez przedsiębiorstwa działań z obszaru środowiska naturalnego, spraw społecznych oraz ładu korporacyjnego, określanych jako dane ESG (od angielskich słów E - environment, S - social, G - governanse). Każdy jednak raport społeczny powinien stanowić kompendium wiedzy dostępnej dla każdego interesariusza celem łagodzenia asymetrii informacji ${ }^{6}$. Stąd też obserwujemy dynamicznie zmieniające się modele biznesowe, które mają zaspakajać oczekiwania interesariuszy. Tym samym rozpowszechniona współcześnie idea zintegrowanego raportowania, która zrodziła się z dbałości o potrzeby informacyjne różnych grup interesariuszy zyskuje coraz większą liczbę zwolenników. Jednocześnie należy zwrócić uwagę, na fakt, iż raportowanie zintegrowane pozwala wykazywać, że przedsiębiorstwo posiada strategię zrównoważonego rozwoju opartą na rzeczywistym zaangażowaniu w społeczną odpowiedzialność oraz że bierze pod uwagę potrzeby wszystkich interesariuszy [Eccles, Krzus 2010].

\footnotetext{
${ }^{5}$ Raportowanie zintegrowane polega na publikacji informacji finansowych, środowiskowych, społecznych i danych z obszaru ładu korporacyjnego w jednym zestawieniu. Ponadto w jasnej, kompletnej i porównywalnej formie przedstawia nie tylko bieżącą kondycję organizacji, ale pokazuje również jej plany na przyszłość [szerzej Sobczyk 2012, s. 155-170, Matuszczyk 2015, s. 153-161].

${ }^{6}$ Zjawisko asymetrii informacji polega na tym, że jedna ze stron transakcji ma pełniejszy dostęp do informacji dotyczących warunków podejmowanych decyzji (inwestycyjnej, finansowej) niż druga [szerzej o asymetrii informacji Błach 2009, s. 100-102], w literaturze przedmiotu wyodrębniane są dwa typy asymetrii informacji: asymetria ex ante (negatywna selekcja), gdy inwestor nie jest w stanie ocenić szans powodzenia projektów inwestycyjnych będących przedmiotem finansowania oraz asymetrię ex post (hazard moralny), gdy kapitałobiorca może podjąć działania niepożądane z punktu widzenia interesów inwestora [szerzej Łukasik 2006, s. 302]. Asymetria informacji jest widoczna w postrzeganiu wartości przedsiębiorstwa przez właścicieli i inwestorów oraz kierownictwo i pracowników, gdyż wynika nie tylko z subiektywnej oceny poszczególnych grup, ale z posiadanej wiedzy. Dlatego istotną rolę spełnia raportowanie pozafinansowe, które pozwala zmniejszać asymetrię informacji między użytkownikami wewnętrznymi informacji z przedsiębiorstwa a różnymi grupami jego interesariuszy.
} 
Wypełnianie natomiastzobowiązań wynikających z deklaracji przedsiębiorstw do przestrzegania zasad CSR stało się impulsem do stworzenia mechanizmów integrujących kwestie społeczne, środowiskowe i etyczne z własną strategią i działalnością, przy jednoczesnej współpracy z interesariuszami. Celem przedsiębiorstw działających w „duchu” CSR przy realizowaniu zobowiązań powinno być nie tylko tworzenie, maksymalizowanie wspólnych wartości dla właścicieli, udziałowców, każdej zainteresowanej strony i społeczeństwa jako całości, ale równoczesne rozpoznawanie, zapobieganie i łagodzenie negatywnych skutków. Interesariusze oczekują nie tylko wysokiej jakości produktów, usług ale również dostarczania ich w sposób niedegradujący środowisko naturalne z jednoczesnym zachowaniem kanonu etycznego. Ponadto inwestorzy przy podejmowaniu decyzji strategicznych coraz częściej większą wartość, przy ocenie kondycji spółek, przypisują danym pozafinansowym ${ }^{7}$, które pozwalają w dużym stopniu odpowiedzieć na pytanie Czy warto zainwestować w wybranq spółkę? oraz Jak ograniczać towarzyszace każdej decyzji ryzyko? Stanowi to potwierdzenie wzrostu rangi raportowania pozafinansowego dla interesariuszy.

Pomimo rosnącego zainteresowania w Polsce koncepcją CSR nadal wiele przedsiębiorstw nie uwzględnia postulatów wypływających z idei opisywanej koncepcji w sposób kompleksowy i przyjmujący wymiar planu strategicznego. Dlatego organizacje chcąc właściwie realizować zasady odpowiedzialnego biznesu powinny w umiejętny sposób zdefiniować potrzeby otoczenia i zbudować mapę interesariuszy, z którymi współpracują lub mogą współpracować. Natomiast przyjęcie długofalowej strategii opartej na potrzebach interesariuszy powinno być zintegrowane ze strategią biznesową i wywoływać zmianę społeczną zarówno w firmie jak i w jej otoczeniu [Ruszczak 2014].

\section{ZMIANY W RAPORTOWANIU CSR}

Od kilkunastu lat można zaobserwować dynamikę zmian w prezentacji danych pozafinansowych ${ }^{8}$. Sposób raportowania prowadzonych przez przedsiębiorstwa działań z zakresu CSR jest dobrowolny. Stąd też przedsiębiorstwa, które decydują

7 Inwestorzy na podstawie sprawozdawczości korporacyjnej oceniają wartość danej firmy, ryzyka i mocne strony jej kierownictwa [Druckman 2013, s. 4].

8 W warunkach globalizacji, ze względu na zmieniające się zapotrzebowanie na informacje ekonomiczne, społeczne i środowiskowe nie tylko ze strony zarządzających jak i coraz częściej różnych grup interesariuszy dokonały się zmiany w podejściu do raportowania. Sprawozdanie finansowe przestano postrzegać jako wyłączne źródło informacji finansowych udostępnianych tylko z mocy przepisów prawa i zaczęto do niego włączać informacje o oddziaływaniu przedsiębiorstwa na otoczenie, które pozwala na zachowanie transparentności [szerzej Jaworska 2011, s. 573-577]. 
się nie tylko na ujawnianie informacji dotyczącej społecznej odpowiedzialności w obligatoryjnym sprawozdaniu rocznym, ale na sporządzaniu odrębnego raportu CSR mają pełną swobodę co do jego formy i prezentacji informacji w nim zawartych. Fakultatywność w sporządzaniu raportów społecznych powoduje, że dokonywanie oceny i porównań prowadzonych działań z zakresu społecznej odpowiedzialności poszczególnych przedsiębiorstw jest trudne. Wobec zaistniałego problemu zaczęto opracowywać i wdrażać standardy mające na celu ujednolicenie raportowania społecznej odpowiedzialności ${ }^{9}$. Wśród międzynarodowych standardów i wytycznych dotyczących raportowania CSR, które zostały wdrożone w wielu krajach na całym świecie są przede wszystkim: wytyczne OECD dla przedsiębiorstw wielonarodowych ${ }^{10}$, wytyczne Global Reporting Initiative (GRI) ${ }^{11}$, wytyczne Global Compact ${ }^{12}$, Norma ISO 26000 [Makuch 2011, Adamczyk 2013, Urbaniec 2015, s. 233, ISO, 2010], które ujęto w tabeli 1.

Najnowsza wersja standardu GRI - G4 jest spójna z dyrektywą UE 2014/95/UE i może stanowić wskazówki dla przedsiębiorstw objętych obligatoryjnym raportowaniem pozafinansowym. Pomimo, że proces raportowania CSR nie opiera się na jednolitych standardach to coraz szerszy dostęp do informacji pozafinansowych powinien przyczyniać się do budowy transparentnej komunikacji pomiędzy uczestnikami rynku nie tylko finansowego. Istotne jest, aby wykazywane w sprawozdaniach informacje były porównywalne, dokładne, terminowe oraz przejrzyste ${ }^{13}$ (tabela 2).

${ }^{9}$ Pierwsza oficjalna próba określenia zasad odpowiedzialnego biznesu została podjęta przez środowiska biznesowe w 1973 r. na trzecim Europejskim Sympozjum Zarządzania, na którym rozpoczęto dyskusję nad stworzeniem systemu sprawozdawczości obejmującej społeczną odpowiedzialność (sformułowano tzw. Manifest z Davos). Niestety wraz $\mathrm{z}$ recesją gospodarczą pod koniec lat siedemdziesiątych XX wieku kwestie dotyczące CSR zostały odsunięte na dalszy plan, wrócono do nich dopiero w latach dziewięćdziesiątych ubiegłego wieku [szerzej Fijałkowska, 2012, s. 141-152, Sobczyk, 2013, s. 156-158].

${ }^{10}$ Wytyczne OECD dla przedsiębiorstw wielonarodowych (OECD Guidelines for Multinational Enterprises) zostały opracowane po raz pierwszy w 1976 r., natomiast ostatniej aktualizacji dokonano w 2011 r. W 2016 r. obchodzone jest 40-lecie zaleceń zawartych w Wytycznych OECD dla Przedsiębiorstw Wielonarodowych oraz mija 20 lat od przystąpienia Polski do OECD.

${ }^{11}$ Celem międzynarodowej organizacji non-profit GRI (Global Reporting Initiative) jest to, aby przedsiębiorstwa raportujące tematykę zrównoważonego rozwoju i społecznej odpowiedzialności włączały ją w swoje decyzje biznesowe.

${ }^{12}$ Global Compact największa na świecie inicjatywa na rzecz odpowiedzialności korporacyjnej i zrównoważonego rozwoju podjęta w 1999 roku przez K. Annana (ówczesnego Sekretarza Generalnego ONZ); obecnie przystąpiło do niej ponad 10000 instytucji i firm z 145 krajów świata.

${ }^{13}$ Szerzej na temat cech jakościowych informacji zawartych w sprawozdaniach por. Pfaff 2008, s. 58-66. 
TABELA 1. Najpopularniejsze międzynarodowe standardy i wytyczne dotyczące raportowania CSR

\begin{tabular}{|l|l|}
\hline $\begin{array}{l}\text { Wytyczne } \\
\text { lub standardy }\end{array}$ & \multicolumn{1}{c|}{ Opis } \\
\hline $\begin{array}{l}\text { Wytyczne } \\
\text { OECD }\end{array}$ & $\begin{array}{l}\text { zbiór zasad i standardów z różnych obszarów, poczynając od praw czło- } \\
\text { wieka, praw pracowniczych i bezpieczeństwa pracy, przez kwestie do- } \\
\text { stępu do ich informacji, opodatkowanie, ochronę środowiska i należytej } \\
\text { staranności w działalności firm }\end{array}$ \\
\hline $\begin{array}{l}\text { Wytyczne } \\
\text { Global Reporting } \\
\text { Initiative (GRI) }\end{array}$ & $\begin{array}{l}\text { ogólne zasady raportowania i szczegółowe zalecenia odnośnie zawarto- } \\
\text { ści raportu społecznego; najnowsza wersja - standard GRI - G4 kładzie } \\
\text { duży nacisk na to, aby raporty uwzględniały perspektywę interesariuszy } \\
\text { i były opracowane w przejrzysty sposób }\end{array}$ \\
\hline $\begin{array}{l}\text { Wytyczne } \\
\text { Global Compact }\end{array}$ & $\begin{array}{l}\text { wezwanie skierowane do świata biznesu, aby kierował się w swojej } \\
\text { działalności 10 fundamentalnymi zasadami z zakresu praw człowieka, } \\
\text { standardów pracy, ochrony środowiska naturalnego i przeciwdziałania } \\
\text { korupcji }\end{array}$ \\
\hline $\begin{array}{l}\text { Norma ISO } \\
26000\end{array}$ & $\begin{array}{l}\text { wskazuje narzędzia wdrażania koncepcji CSR o charakterze uniwersal- } \\
\text { nym, jakie mogą być zastosowane zarówno w organizacjach publicznych, } \\
\text { prywatnych jak i non profit - niezależnie od wielkości }\end{array}$ \\
\hline
\end{tabular}

Źródło: Opracowanie własne.

TABELA 2. Cechy informacji wykazywanych w raportach społecznych

\begin{tabular}{|l|l|}
\hline Cecha informacji & Opis \\
\hline Porównywalność & $\begin{array}{l}\text { Kwestie i informacje zawarte w raporcie powinny być dobierane, ze- } \\
\text { stawiane i w sposób spójny i konsekwentny umożliwiający interesa- } \\
\text { riuszom przeanalizowanie zmian w wynikach spółek, organizacji wraz } \\
\text { z upływem czasu oraz porównanie ich z wynikami innych podmiotów. }\end{array}$ \\
\hline Dokładność & $\begin{array}{l}\text { Przedstawiane w raporcie dane powinny być na tyle dokładne i szcze- } \\
\text { gółowe, aby interesariusze mogli ocenić wyniki przedsiębiorstwa, or- } \\
\text { ganizacji raportującej }\end{array}$ \\
\hline Terminowość & $\begin{array}{l}\text { Raporty powinny być sporządzane regularnie, aby dostępne w odpo- } \\
\text { wiednim czasie informacje umożliwiały interesariuszom świadome } \\
\text { podejmowanie decyzji. }\end{array}$ \\
\hline Przejrzystość & $\begin{array}{l}\text { Udostępniane w raportach informacje powinny być zrozumiałe i do- } \\
\text { stępne dla interesariuszy }\end{array}$ \\
\hline
\end{tabular}

Źródło: Na podstawie pracy zbiorowej pod. red. Ćwik 2013, s. 85.

Informacje udostępniane interesariuszom muszą odznaczać się zatem kilkoma cechami jakościowymi, które zapewniają odpowiednią użyteczność każdej informacji. Ponadto raporty CSR powinny podlegać weryfikacji, aby móc ustalić jakość i istność informacji. Tym bardziej, że rosnąca ranga sprawozdawczości pozafinansowej przedsiębiorstw jest wynikiem coraz większych oczekiwań interesariuszy co do transparentności i odpowiedzialności przedsiębiorstw, implikujących po- 
miar oraz ocenę wpływu podejmowanych decyzji biznesowych na społeczeństwo i środowisko naturalne [Sparkes, Cowtown 2004, s. 48; Tilt 2007, s. 104].

Raportowanie społeczne jako systematyczny proces komunikowania się przedsiębiorstwa z interesariuszami staje się na świecie standardem, pomimo, że udostępnianie danych niefinansowych jest dobrowolne. Na skutek jednak implementacji unijnej dyrektywy 2014/95/UE od dn. 01.01.2017 r. europejskie spółki, organizacje spełniające określone wymogi będą zobligowane do raportowania tzw. danych pozafinansowych ${ }^{14}$. Ujawnianie zatem danych z zakresu CSR w związku z wytycznymi zawartymi w Dyrektywie UE 2014/95/UE stanie się dla niektórych przedsiębiorstw obligatoryjne. Warto jednak podkreślić, iż rozszerzenie sprawozdawczości o dodatkowe informacje niefinansowe - raporty CSR w odniesieniu do określonych w przepisach prawa przedsiębiorstw będzie nadal miała charakter dobrowolny ${ }^{15}$.

\section{KONCEPCJA BADAŃ}

Rosnące znaczenie odpowiedzialności przedsiębiorstwa wobec otoczenia wpłynęło na wzbogacenie sprawozdawczości jednostek o raporty środowiskowe, społeczne, etyczne oraz uwzględnienie kwestii związanych z kontaktami z interesariuszami.

W zakresie przedmiotowym badania skierowano na wskazanie kanałów raportowania działań CSR przez spółki notowane na głównym rynku Giełdy Papierów Wartościowych w Warszawie S.A. w ramach indeksu WIG 30. Analiza zebranego materiału badawczego została ukierunkowana na uzyskanie odpowiedzi na następujące pytanie: Czy badane spółki raportują działalność z zakresu odpowiedzialności społecznej $w$ raportach rocznych, czy $w$ raportach specjalnie dedykowanych CSR? Dzięki temu będzie można stwierdzić jak często spółki decydują się na przygotowanie raportu zintegrowanego oraz czy ewentualne sporządzanie

${ }^{14}$ Parlament UE rozszerzając obowiązki sprawozdawcze dużych spółek kierował się potrzebą zwiększenia dostępu informacji z zakresu tematyki społecznej i środowiskowej znajdującej swoje odzwierciedlenie w tzw. społecznej odpowiedzialności przedsiębiorstw (CSR) przy jednoczesnej poprawie ich spójności i porównywalności.

${ }^{15}$ Obecnie w Polsce raporty CSR sporządzają przede wszystkim spółki giełdowe GPW w Warszawie, wchodzące w skład Respect Index. W świetle nowych przepisów, spółki te będą mogły wywiązywać się z dodatkowych obowiązków sprawozdawczych poprzez publikowanie odrębnych raportów CSR pod warunkiem, że będą one zawierały minimum informacji niefinansowych wskazanych w Ustawie o rachunkowości. Natomiast jednostki, które nie będą zainteresowane odrębną sprawozdawczością niefinansową, będą mogły wykazać wszystkie wymagane informacje w sprawozdaniu z działalności jako wyodrębnioną jego część o nazwie „Oświadczenie na temat informacji niefinansowych”. 
takiego raportu ma związek z równoczesnym prezentowaniem (lub nie) takich informacji w sposób tradycyjny (obligatoryjne roczne sprawozdanie) bądź w raportach dodatkowych (tzw. raportach społecznych).

Na potrzeby badań jako materiał źródłowy wykorzystano informacje zawarte w sprawozdaniach za lata 2013-2015 spółek notowanych na GPW w Warszawie S.A. należących do WIG 30 dostępnych za pomocą stron internetowych. Podmiotami wybranymi do analizy są spółki, które od 2017 r. w związku z wytycznymi zawartymi w Dyrektywie UE 2014/95/UE będą zobowiązane do ujawniania danych niefinansowych, w tym z zakresu CSR.

\section{WYNIKI BADAŃ I DYSKUSJA}

Zebrany materiał badawczy dotyczący kanałów raportowania danych z zakresu CSR przez spółki notowane na głównym rynku GPW w Warszawie S.A. w ramach indeksu WIG 30, z podziałem na sektory zaprezentowano w tabeli 3 . Dane te poddane zostały analizie w przekroju sektorowym, przy czym wśród wybranych do badania spółek WIG 30:9 spółek należy do przemysłu, 12 spółek należy do usług, a 9 spółek zaklasyfikowano do sektora finansowego. ${ }^{16} \mathrm{Z}$ zestawienia ujętego $\mathrm{w}$ tabeli 3 wynika, że raport zintegrowany został sporządzony za rok obrotowy 2013 tylko przez 3 spółki z indeksu WIG 30, za rok 2014 przez 5 spółek, a za rok 2015 przez 6 spółek [PKN ORLEN, LOTOS, KGH, LWB, ATT i PGE]. Jednocześnie spośród 6 spółek, które zdecydowały się na wprowadzenie zintegrowanego raportu rocznego tylko jedna zamieszcza nadal informacje z zakresu CSR w bilansie [LOTOS] lub sporządza dodatkowo raport społeczny [ATT]. Z kolei specjalny raport z zakresu CSR za rok 2013 sporządziło 11 spółek, za rok 2014 - 9 spółek, a za rok 2015 tylko 6 spółek. Udostępnianiu zatem informacji interesariuszom przez spółki WIG $30 \mathrm{w}$ formie raportów CSR odnotowuje tendencję spadkową. Zamieszczanie natomiast informacji z zakresu CSR w bilansie wciąż jest najbardziej powszechne. Ponadto fakt wykazywania informacji pozafinansowych przez spółki WIG $30 \mathrm{w}$ raportach społecznych nie doprowadził do rezygnacji ujmowania danych z zakresu CSR w bilansie. Analizując dane za rok $2015 \mathrm{w}$ każdej z grup w kontekście sporządzania raportu zintegrowanego - stwierdzono, że liderem jest sektor - przemysłowy.

Spośród 9 spółek z grupy przemysł łącznie 5 sporządziło w 2015 r. raport zintegrowany. W roku 2013 raport taki sporządziły 3 spośród badanych spółek (LOTOS, KGH, ATT), w roku 2014 dodatkowo spółka (PKN ORLEN i LWB), przy czym dane pozafinansowe w 2015 roku jedna ze spółek (ATT) udostępnia zarówno w raporcie zintegrowanym jak i dedykowanym CSR. Są to spółki, które zdecydowały się na odejście od odrębnych raportów CSR. Wyjątkiem jest spółka PGN, która w 2015 r. odeszła

${ }^{16}$ https://www.gpw.pl/ 
TABELA 3. Sposoby raportowania działań o odpowiedzialności społecznej w badanych spółkach

\begin{tabular}{|c|c|c|c|c|c|c|c|c|c|c|}
\hline \multirow[b]{2}{*}{ Lp. } & \multirow[b]{2}{*}{ Nazwa spółki } & \multicolumn{3}{|c|}{2013} & \multicolumn{3}{|c|}{2014} & \multicolumn{3}{|c|}{2015} \\
\hline & & Bilans & $\begin{array}{l}\text { Rap. } \\
\text { CSR }\end{array}$ & \begin{tabular}{|c|} 
Rap. \\
Zintegr. \\
\end{tabular} & Bilans & $\begin{array}{l}\text { Rap. } \\
\text { CSR }\end{array}$ & \begin{tabular}{|c|} 
Rap. \\
Zintegr. \\
\end{tabular} & Bilans & $\begin{array}{l}\text { Rap. } \\
\text { CSR }\end{array}$ & $\begin{array}{l}\text { Rap. } \\
\text { Zintegr. }\end{array}$ \\
\hline \multicolumn{11}{|c|}{ PRZEMYSŁ } \\
\hline 1 & PKN ORLEN & 1 & 1 & - & - & - & 1 & - & - & 1 \\
\hline 2 & LOTOS & 1 & - & 1 & 1 & - & 1 & 1 & - & 1 \\
\hline 3 & PGN & 1 & 1 & - & 1 & 1 & - & 1 & - & - \\
\hline 4 & KGH & 1 & - & 1 & - & - & 1 & - & - & 1 \\
\hline 5 & JSW & 1 & - & - & 1 & - & - & 1 & - & - \\
\hline 6 & LWB & 1 & 1 & - & - & - & 1 & - & - & 1 \\
\hline 7 & SNS & - & - & - & - & - & - & 1 & - & - \\
\hline 8 & ATT & - & 1 & 1 & - & 1 & 1 & - & 1 & 1 \\
\hline 9 & KER & - & - & - & 1 & - & - & 1 & - & - \\
\hline Raze & m PRZEMYSŁ & 6 & 4 & 3 & 4 & 2 & 5 & 5 & 1 & 5 \\
\hline \multicolumn{11}{|c|}{ USŁUGI } \\
\hline 10 & LPP & - & - & - & - & - & - & 1 & - & - \\
\hline 11 & CCC & - & - & - & - & - & - & 1 & - & - \\
\hline 12 & EUR & 1 & - & - & 1 & - & - & 1 & - & - \\
\hline 13 & CDR & - & - & - & - & - & - & - & - & - \\
\hline 14 & ACP & - & - & - & - & - & - & - & - & - \\
\hline 15 & CPS & 1 & - & - & 1 & - & - & 1 & - & - \\
\hline 16 & OPL & 1 & 1 & - & 1 & 1 & - & 1 & - & - \\
\hline 17 & PGE & 1 & 1 & - & 1 & 1 & - & - & - & 1 \\
\hline 18 & ENA & 1 & 1 & - & 1 & 1 & - & 1 & 1 & - \\
\hline 19 & TPE & 1 & - & - & 1 & - & - & 1 & - & - \\
\hline 20 & ENG & 1 & 1 & - & 1 & 1 & - & 1 & 1 & - \\
\hline 21 & PKP & - & - & - & - & - & - & - & - & - \\
\hline & zem USŁUGI & 7 & 4 & 0 & 7 & 4 & 0 & 8 & 2 & 1 \\
\hline \multicolumn{11}{|c|}{ FINANSE } \\
\hline 22 & PZU & 1 & 1 & - & 1 & 1 & - & 1 & - & - \\
\hline 23 & MIL & 1 & - & - & 1 & - & - & - & 1 & - \\
\hline 24 & ING & 1 & 1 & - & 1 & 1 & - & 1 & - & - \\
\hline 25 & PEO & 1 & - & - & 1 & - & - & 1 & - & - \\
\hline 26 & PKO & 1 & - & - & 1 & - & - & 1 & - & - \\
\hline 27 & ALR & 1 & - & - & 1 & - & - & 1 & - & - \\
\hline 28 & MBK & 1 & - & - & 1 & - & - & 1 & 1 & - \\
\hline 29 & BZW & 1 & 1 & - & 1 & 1 & - & 1 & 1 & - \\
\hline 30 & GTC & - & - & - & - & - & - & 1 & - & - \\
\hline \multicolumn{2}{|c|}{ Razem FINANSE } & 8 & 3 & 0 & 8 & 3 & 0 & 8 & 3 & 0 \\
\hline \multicolumn{2}{|c|}{$\begin{array}{c}\text { Razem wszystkie } \\
\text { spółki }\end{array}$} & 21 & 11 & 3 & 19 & 9 & 5 & 21 & 6 & 6 \\
\hline
\end{tabular}

Źródło: Opracowanie własne na podstawie informacji wykazanych w sprawozdaniach spółek WIG 30. 
od sporządzania raportu CSR na rzecz uwzględnienia informacji o takich działaniach w ramach sprawozdania finansowego. W tej grupie spółek wyraźnie zatem rysuje się trend wskazujący na odchodzenie od raportowania działań CSR w raportach dedykowanych i umieszczanie takich informacji w raporcie zintegrowanym.

\section{WNIOSKI}

Obecnie dokumentami podsumowującymi zaangażowanie spółek WIG 30 w projekty z zakresu społecznej odpowiedzialności biznesu są przede wszystkim raporty roczne. Natomiast raportowanie zintegrowane jest niewielkie. Należy podkreślić, iż spółki które zdecydowały się na publikowanie zintegrowanych raportów odstąpiły od sporządzania odrębnego raportu z zakresu CSR.

Zachowanie przejrzystości prowadzonej działalności powinno obligować przedsiębiorstwa nie tylko do raportowania kwestii finansowych (ekonomicznych), ale i szeroko rozumianych danych pozafinansowych (społecznych, środowiskowych) znajdujących swoje odzwierciedlenie w idei CSR. Ponadto dzięki koncepcji CSR jako procesu ciągłego samodoskonalenia w celu podejmowania konsekwentnych i długoterminowych działań społecznie odpowiedzialnych poprzez sporządzanie raportów społecznych możliwe jest nie tylko budowanie, ale i utrzymywanie i wzmacnianie relacji z interesariuszami.

Raportowanie pozafinansowe w Polsce jest dopiero w początkowej fazie rozwoju, przy czym polska praktyka w zakresie raportowania CSR może się już pochwalić firmami, które wdrożyły stosowane na świecie standardy w zakresie raportowania m.in. CSR ${ }^{17}$. Polscy liderzy raportowania danych z zakresu CSR mogą wykorzystać nowy obowiązek jako szansę wzmacniającą ich pozycję na rynku, a jednocześnie stanowiącą impuls do przejścia na raportowanie zintegrowane (umożliwiające prezentację przedsiębiorstw w krótko-, średnio- i długoterminowej perspektywie ${ }^{18}$ ). Dzięki ujawnianiu danych z obszaru CSR przedsiębiorstwa nie tylko sprostają nowym wymogom sprawozdawczym, ale i zyskają większe zaufanie ze strony inwestorów.

\footnotetext{
${ }^{17}$ W 2014 r. spośród 31 raportów zgłoszonych do konkursu Listki CSR Polityki - Raporty Społeczne, 28 zostało przygotowanych w oparciu o międzynarodowy standard Global Reporting Initiative (GRI). Natomiast największą polską inicjatywą promującą tematykę CSR jest konkurs Raporty Społeczne, organizowany od 2007 roku w partnerstwie FOB, Deloitte i SGS (wcześniej PWC i CSR Consulting), w którym co roku nagradzane są najlepiej sporządzone sprawozdania (oprócz nagrody głównej i wyróżnień przyznawanych przez jury konkursu wręczane są dyplomy dla najlepszych raportów w ocenie Ministra Gospodarki, jury dziennikarskiego i internautów).

${ }^{18}$ Rok 2011 uznawany jest jako moment rozpoczęcia procesu konsultacji pierwszej wersji wytycznych w zakresie raportowania zintegrowanego
} 
Zpespektywyinteresariuszyrezultatem raportowaniadanychpozafinansowych są głównie publikacje podsumowujące działania z zakresu CSR. Niestety w Polsce tematem raportowania pozafinansowego zajmują się głównie duże przedsiębiorstwa. Ze względu na wysoka wartość poznawczą tą problematyką powinny być zainteresowane również administracja publiczna, organizacje pozarządowe oraz sektor małych i średnich przedsiębiorstw. Opisywany obszar raportowania powinien skupiać wszystkie przedsiębiorstwa i instytucje strategicznie podchodzące do zagadnienia społecznej odpowiedzialności, tym bardziej że raportowanie pozafinansowe zmniejsza asymetrię informacji.

\section{Spis literatury}

ADAMCZYK J. 2013: Raportowanie społecznej odpowiedzialności przedsiębiorstw, Przegląd Organizacji, nr 4, s. 8-12.

ADAMUS-MATUSZYŃSKA A. 2017: Mapa interesariuszy w strategii CSR a mapa publiczności w działalności PR, http://www.proto.pl/artykuly/mapa-interesariuszy-w-strategii-csr-mapa-publicznosci-w-dzialalnosci-pr (dostęp na 30.06.2017 r.)

BŁACH J. 2009: Ewolucja teorii struktury kapitału, Finanse Vol. 1 Nr 1, s. 67-106.

ĆWIK N. (RED.) 2013: ROLA RAPORTOWANIA SPOŁECZNEGO, FOB, WARSZAWA.

DRUCKMAN P. 2013: Corporate reporting: rising to the challenge, World Federation of Exchanges Focus, no. 249.

Dyrektywa UE 2014/95/UE w odniesieniu do ujawniania informacji niefinansowych i informacji dotyczących różnorodności przez niektóre duże spółki oraz grupy.

ECCLES R.G., KRZUS M.P. 2010: One Report, Integrated Reporting for a Sustainable Strategy, John Wiley and Sons, Inc., New Jersey.

FIJAŁKOWSKA J. 2012: Społeczna odpowiedzialność wyzwaniem dla rachunkowości, Przedsiębiorczość i Zarządzanie, Vol. XIII, z. 1, s. 141-152.

FREEMAN R.E. 1984: Strategic Management: A Stakeholders Approach, Pitman Publishing Company, Boston.

GASPARSKI W. 2003, Europejskie standardy etyki i społecznej odpowiedzialności biznesu, WSPiZ, Warszawa.

JAWORSKA E. 2011: Zmiana podejścia do sprawozdawczości w aspekcie społecznej odpowiedzialności przedsiębiorstw, Zeszyty Naukowe Uniwersytetu Szczecińskiego, nr 266, Finanse, Rynki Finansowe, Ubezpieczenia nr 411, s. 573-577.

ŁUKASIK G. 2006: Konflikty interesów uczestników rynku kapitałowego i ich wpływ na wybory przedsiębiorstwa w: Rynki finansowe, red. H. Mamcarz, UMCS, Lublin.

MAKUCH Ł. 2011: Normy i standardy społecznej odpowiedzialności biznesu (CSR) Przewodnik po kluczowych standardach społecznej odpowiedzialności biznesu oraz relacjach i współzależnościach pomiędzy nimi zachodzących, Wyższa Szkoła Pedagogiczna TWP, Warszawa. 
MATUSZCZYK I. 2015: Raportowanie zintegrowane w komunikacji przedsiębiorstwa z otoczeniem, Zeszyty Naukowe Uniwersytetu Szczecińskiego nr 855 Finanse, Rynki Finansowe, Ubezpieczenia nr 74, t. 2, s. 153-161.

PINDELSKI M. 2009: Tworzenie przewag konkurencyjnych z wykorzystaniem społeczności sieciowych, Oficyna Wydawnicza SGH, Warszawa.

PFAFF J., 2008: Wpływ rewizji finansowej na wiarygodność sprawozdania finansowego, Wyd. AE w Katowicach, Katowice, s. 58-66.

ROK B. 2010: Instytucjonalizacja społecznej odpowiedzialności przedsiębiorstw. Perspektywa teoretyczna i strategia badawcza [w:] Oblicza społecznej odpowiedzialności przedsiębiorstw, Wydawnictwo Naukowe SCHOLAR, Warszawa.

RUSZCZAK A. 2014: Dokumenty społecznej odpowiedzialności firm, Kwartalnik - Człowiek i dokumenty, http://ww1.pwpw.pl/kwartalnik_archiwum.html?id=44\&magCid=219 (dostęp na 30.06.2017 r.).

SOBCZYK M. 2013: Podstawy teoretyczne koncepcji zintegrowanego raportowania, „Studia i Prace Kolegium Zarządzania i Finansów", z. 130, s. 156-158.

SOBCZYK M. 2012: Zintegrowane raportowanie - nowy model raportowania biznesowego, , Przedsiębiorczość i Zarządzanie, Wydawnictwo SAN - ISSN 1733-2486, Tom XIII - Zeszyt 1, s. 155-170.

SPARKES R., COWTOWN C.J. 2004: The maturing of socially responsible investment: a review of the developing link with Corporate Social Responsibility, Journal of Business Ethics, Vol. 52(1), s. 45-57.

SROKA R. GRZYMISŁAWSKI A., KUSTRA A., 2012: Wytyczne w zakresie ujawniania danych dotyczących przedsiębiorstw, ekspertyza przygotowana dla Ministerstwa Gospodarki przez Accreo Taxand oraz Akademię Górniczo-Hutniczą, http://www.mg.gov.pl/files/ upload/10892/ Ekspertyza\%20’Wytyczne\%20w\%20zakresie\%20ujawniania\%20da nych\%20pozafinans.pdf

URBANIEC M. 2015: Raportowanie CSR jako narzędzie doskonalenia działalności biznesowej, Prace Naukowe UE we Wrocławiu, Zrównoważony rozwój organizacji-aspekty społeczne, nr 378, s. 228-242.

ZBIEGIEŃ-MACIĄG L. 1997: Etyka w zarządzaniu, Wydawnictwo Centrum Informacji Menedżera, Warszawa.

ISO 26000 (2010), Guidance on Social Responsibility, International Organization for Standardization, Geneva.

\section{CHANGES IN CSR REPORTING IN POLAND - A CASE STUDY}

Abstract. The aim of this article is to present the changes in non-financial reporting and reporting channels of CSR data by companies listed on the main market of the Warsaw Stock Exchange within the WIG 30. Analyses show that companies are diverging from showing information in the field of CSR in traditional financial 
statements and decide on the disclosure of CSR in special reports and on their websites. In addition, Polish leaders of non-financial reporting, decided to prepare integrated annual reports. Although social reporting in Poland is still a new area, practice indicates on the dynamics of development in the field of reporting non-financial data.

Key words: corporate social responsibility, social reports, non-financial reporting 